\title{
ANALYSIS ON ADMINISTRATIVE SERVICES IN DENTAL POLY CLINIC PLK UNAIR 2017
}

Analisis Pelayanan Administrasi di Poli Gigi Klinik PLK UNAIR 2017

Jaqueline Kerina ${ }^{1}$, Ernawaty ${ }^{2}$

1,2Department of Health Policy and Administration, Faculty of Public Health, Universitas Airlangga, Indonesia

E-mail: jkerina0@gmail.com

\begin{abstract}
Service delivery and healthcare have recently received increasing attention. Pusat Layanan Kesehatan Universitas Airlangga (PLK UNAIR) is in a network with various hospitals and government insurance agencies in assurance of best healthcare service for the community. The objective of this study is to describe the flow of the administrative services in the dental unit of PLK UNAIR. This study followed qualitative design approach and study was explorative through active participation, conducted interviews and observations. Results drawn from this study showed that the flow of administrative services, PLK UNAIR has accomplished its objectives through the contribution of its employees. The summary shows the identification of patient flow in PLK UNAIR dental unit. It is evident that PLK receives a high influx of patients a lot that happens to be students and at a friendly rate.
\end{abstract}

Keywords: administration, patients, services, students

\section{ABSTRAK}

Penyediaan layanan dan perawatan kesehatan akhir-akhir ini mendapatkan perhatian yang semakin meningkat. Pusat Layanan Kesehatan Universitas Airlangga (PLK UNAIR) berada dalam jaringan dengan berbagai rumah sakit dan agen asuransi pemerintah dalam menjamin layanan kesehatan terbaik bagi masyarakat. Tujuan penelitian ini adalah untuk mendeskripsikan arus pelayanan administrasi di unit gigi PLK UNAIR. Penelitian ini menggunakan desain penelitian kualitatif eksploratif melalui partisipasi aktif, wawancara dan observasi. Hasil dari penelitian ini menunjukkan bahwa alur pelayanan administrasi PLK UNAIR telah sesuai dengan tujuannya berdasarkan kontribusi karyawannya. Ringkasan menunjukkan identifikasi aliran pasien di unit gigi PLK UNAIR. Hal ini menunjukkan bahwa PLK menerima banyak pasien mahasiswa pada waktu tertentu.

Kata Kunci: administrasi, penderita, pelayanan, mahasiswa

\section{INTRODUCTION}

Healthcare services are essential services to everyone. The utmost importance of healthcare provides better access and faster diagnosis to the patients. According to Douglas \& Douglas (2004), administration is a planned job done by a group of people working together to achieve the objectives on the basis of an effective, efficient and rational administration. Administrators are the main pioneers of the clinic. As a result, administrative services are catered in a way to satisfy patients. Administrators involve activities that have goals and procedures for attaining them. In accordance with patient satisfaction and patient expectation, administrators are expected to deliver the utmost quality service to the patients and ensure a clean and healthy environment. Service deliverance matters to all and administrators are expected to perform their task effectively. The number of patients visiting PLK, especially the students from UNAIR, are easy access to the facility due to its location and treatments at a friendly rate. It is estimated that during the period of 13 February to 10 March 2017 morning hours, 162 patients visited the
Poly Dental Unit in PLK UNAIR while 197 patients were seen during afternoon hours. A total number of 359 patients were treated during the period mentioned above. These statistics will be later illustrated in a table format. However, the influx of patients' daily visits to PLK UNAIR has raised an eye brow. The facility has fixed standards that are implemented to meet the needs of patients. PLK UNAIR comprises of 28 staff on board. The job description is structured according to the utility of the institution. As viewed from the organizational structure, management level in PLK UNAIR is viewed on its efficiency in various departments, and the structure helps employees to understand the chain of command. Various departments in PLK UNAIR are grouped in order to promote the efficiency of the facility. These groupings are generally done according similarity of duties. As a result, each employee is assigned to perform a required task at an appropriate time. The institution is then geared towards the performance of the employees with the sense of attaining its goal by: How are the general description and the institutions structure in PLK UNAIR? How is the overview of job description in the Dental Unit in PLK UNAIR? 
How to identify the administrative services in the dental unit PLK UNAIR? How is the flow of patients in the dental unit in PLK UNAIR? How is the flow of administrative services in the dental unit in PLK UNAIR? The questions asked above are to analyze the general description and the institutions' structure in PLK UNAIR, and to analyze the overview of the job description in the dental Unit in PLK as well as analyzing the identification of administrative services in the dental unit in PLK UNAIR. It analyze the flow of patients in the dental unit in PLK UNAIR and analyze the flow of administrative services in PLK UNAIR. The objective of this study is to describe the flow of the administrative services in the dental unit at PLK UNAIR. Results drawn from this study is to analyze the general description and the institutional structure in PLK UNAIR, the overview of the job description within the dental unit, and the flow of patients in the dental unit.

\section{METHOD}

The nature of this study was exploratory through active participation, conducted interviews and observations and used qualitative design approach. The data were collected through direct observation and field analysis related to the past apprenticeship which was based on administrative services in the poly dental in PLK UNAIR. The time and location conducted for this study took place from 13 February to 10 March 2017 in PLK UNAIR Kampus B. The study was only limited to Surabaya on all employees of all categories (Medical Doctors, Dentists, Medical nurses, Dental nurses, administrators, general officers) and all staff on board working at PLK UNAIR. The data collection technique was based on internship activities. The secondary data was collected upon the request of a soft file with various documents. The population sample of 28 (PLK UNAIR Staff on board) was drawn through secondary data collection including the number of patients' daily visits amounting to 359 during the period of 13 February 2017 to 10 March 2017. This study does not include interview questionnaire neither validity test was conducted. However, interview was conducted face to face with the employees at PLK UNAIR. This study is derived from apprenticeship crude data were collected during the apprentice process.

\section{RESULTS AND DISCUSSIONS}

Administration can be defined as the activities of groups cooperating to accomplish common goals Thompson (1991). Dangling modifier problem administration is defined as a cooperative human action or cooperative group behavior. Administration is a determinative function, which makes it important. Administration can be defined as a set of cooperative activities undertaken by organizations to accomplish significant and common goals. Administration is a process of cooperation between two or more/a group of people based on rationality to achieve a predetermined goal (Stillman, 2008). Administration as a human effort. Administration in a wider sense is a collaborative activity undertaken by a group of people based on the division of job description as specified in the organizational structure, utilizing resources to achieve goals effectively (Stillman, 2008). As described above, effectively, administrators are engineers operators for the organization. They control the major part of the network that is in the institution. In this very instance, administrators in PLK UNAIR guide patients and have the potential to control the institution. They coordinate, compile data, and generate information among themselves. Make sure everything is in the right place and the right time. Administrators in PLK UNAIR are trained in a way that they would have the capacity to do things everyone else would do. The information in PLK UNAIR is shared based on the managers' rules and new ideas. Plans are addressed urgently with a precision that focuses on doing things right. Administrators' role is unique and complementary to PLK UNAIR. It had created a stable environment in which patients feel to come back all the time and helped other workers to have a long-term goal for PLK UNAIR. Administrators in particular, have deepest aspirations with PLK UNAIR and are able to satisfy patients simultaneously.

The theory of Henry Fayol as described in this study is constructed on personal reflection and involvement of what functioned soundly in the organizations with which he was familiar with based on (Devers, et al., 2009). It is based on how management interacts with personnel. The theory in particular, covers 5 basic elements of administration that management should interact with personnel in order to control and plan production. These elements are planning, organizing, staffing, directing and controlling. These elements are basically the managers' functions. Develop a strategy that will enable the organization to achieve a goal. Once the strategy is clear, best resources can be achieved in the optimum manner. These key elements are in practiced by PLK UNAIR. The management has developed a strategic planning for the workers in order to achieve its goal. The 14 principles of Henry Fayol in management are in practice, and the good results are being produced. These 14 principles are system driven and modern management according to Fayol (1916). Mary Follett (1920), argues that management is the "art of getting things done through people". As mentioned in the first paragraph, the argument above has a positive relationship with administration (Mbalamula, et al., 2017)

The administration gets things done which is an activity done by people in the group. Administration is also an activity to finish all tasks together with several people in a group. However, administrators do things directed by the management; the organization depends on administrators in order to run the organization effectively and efficiently.

Interview conducted on employees as discussed in the method, result showed that administrators are front runners of the organization. It is evident that the information collected through the administrators is clear and correct. It indicates that PLK UNAIR receives a high influx of patients a lot that are 
students at a friendly rate. The flow of administrative services including patients is conducted to view the consistency of administrators and nurses based on the PLK management policy. The vision, mission of PLK UNAIR as described in the Profile Book accelerated the students' learning process on a professional platform and providing the community with the affordable healthcare. Results showed that PLK UNAIR towards future endeavours empowers the community with knowledge, services, and health support the community may need to make better life changes. PLK UNAIR skilled workers and administrators possess unique qualities of character, spirit and teamwork. In addition, they are in close collaboration with BPJS by providing services to the community. PLK provides UNAIR students free services and a few dental treatments at a friendly rate. PLK is committed to foster the community's health related issues and provide quality care.

\section{BPJS and Collaboration with PLK UNAIR}

PLK UNAIR and BPJS had emerged in the middle of 2015 with the formation to cater for quality service and enhance the health of the community. The aspect of collaboration is to refer dental patients for further specialist treatment to various agencies in the same network with PLK UNAIR. The results showed that any patient who may seek services with PBJS, is obligated to visit the first health facility (PLK UNAIR) in order to qualify for treatment under the BPJS services. This has paved way to administrative service to be much more efficient and effective. The administrative service in PLK UNAIR quality service is catered according to the standards of the clinic. According to BPJS, patients are prompted to follow regulation to avoid facing disappointments.

BPJS has made it mandatory to come up with an affordable health insurance policy for the poor, middle and upper class. This could result in reducing bureaucracies among the donors and rather focus on providing protection against social and economic risks. This could justify the needs of the lower class community. It is evident that all participants should be eligible in order to qualify for the program.

Furthermore, according to the Indonesia Ministry of Health BPJS guaranteed dental health services include patients enrollment and fee schedules. Results show that all patients should follow procedures and regulations. Referrals should be done by authorized physician before eligible for any treatment. For administrative services on dental treatment, it is indicated clearly that patients should show their identity and insurance cards in order for the administrators to record the biodata in the system.

Service in PLK UNAIR is catered according to the facility level. Service can be described as the activity or result that an agency can offer to other parties that are usually invisible and results cannot be owned by such other party. According to (Hadipranata, 1996), argues that service is an additional activity beyond the task description provided to customers and is perceived on both respects.

\section{Pusat Layanan Kesehatan Universitas Airlangga (PLK UNAIR)}

PLK UNAIR was established in 2008 and comprises of a sizable staff. It is the first health facility designed to administer basic medical services while a clinic, in particular, organizes specialists medical care and administers both basic medical and specialist services according to Indonesia Minister of Health (2014). PLK UNAIR was formulated as the right hand of the government. Meaning, the employees are to conform to the requirements and regulations of the institution.

PLK UNAIR has a form of support and is accelerated to empower the community through health awareness programs and available for apprenticeship for Students. The merging of UNAIR together with BPJS, is a formation of service, curative, preventing and promoting the sense to prolong the lives of and the health of the community overall. BPJS as a result of dental health services, administrative services should be efficient and that all administrators to participate effectively. PLK UNAIR as the first health facility comprises the Profile Book to showcase services that are in network with the BPJS. It is quite evident that the overall community is motivated to participate in various health programs. PLK UNAIR is open to every walk of life. The high influx of patients' daily visits result in its friendly rates and it is quite accessible especially to UA Students and senior citizens.

\section{Standard Operational Procedures on Patient Admission in PLK UNAIR}

According to the SOP of PLK UNAIR for patient admission, it is essential for every clinic to reach excellence performance. In this regard, PLK UNAIR is maintaining its values towards the hospital standards. The treatment rooms are sterilized prior to the patient's appointment time and ensure readiness for services provided to the patients. PLK UANIR comprises of three values namely aim, readiness and procedure. These values encompass the effectiveness of PLK towards the admission of the patients.

Patient acceptance is the first service provided by the hospital of the Health Care Facilities as described by (Douglas \& Douglas, 2004). It identifies patients upon arrival whether they are in the right place. Judgements from the patients result as the first impression. As described in the study, evidence shows that the first impression is the utmost element for every clinic to win patients and also to evaluate the quality service and what level to improve. It can be viewed that patients always have high expectations towards quality service. Patients opt for prompt assistance and expect the best from the administrators. The readiness by which the doctors response is fast and efficient. Administrators in PLK UNAIR provide patients the information that they need. As indicated above, the first impression is vital. The administrators share information among themselves to acquire speedy processes within the clinic. 
As debated earlier in the study, empathy is practiced efficiently in PLK. Every patient is treated evenly, and no any mistreatments have been reported. Every patient is treated according to what he/she has brought to the clinic and not by class. Most patients feel comfortable in a clean and healthy place. The table on Human resource and total number of workers is depicted on the below.

Based on table 1, traces shows the different levels and positions of workers in PLK UNAIR 2017. Each position is mentioned in sequence respectively. Chairman of PLK summed up to 1, and secretary 1,

Table 1. Human Resources and the Total Number of the Workers in PLK UNAIR 2017

\begin{tabular}{lc}
\hline \multicolumn{1}{c}{ Office } & Total \\
\hline Chairman & 1 \\
Secretary & 1 \\
General Administrative Coordinator & 1 \\
Administration: & \\
$\quad$ a. Financial Administration 2 org & 7 \\
$\quad$ b. Marketing Administration1 org & \\
$\quad$ c. Administration Services 4 Org & \\
General Doctors & 4 \\
Dentists & 4 \\
General / Medical nurses & 4 \\
Dental nurses & 4 \\
General administration & 2 \\
\hline Total & 28 \\
\hline
\end{tabular}

Source: Company Profile PLK UNAIR 2017

General Administrative Coordinator, each sum up to 1, while Finance Administration is 2, Marketing Administrative 1, and Administration Services 4 while general doctors and dentists counts to 4 and General Medical nurses are 4 followed by 4 Dental nurses. All operate and obligated under one flag. PLK UNAIR accomplishes its objectives through the contribution of its employees. Structural decisions are made for the necessity of various activities, the flow of information needed by the decision-makers. Goal achievement has been directed according to the tasks performed by the employees as well as activities within the entire institution. Employees are the drivers and the most important asset to the organization (PLK, 2017). They are the right hand of operations within the institution. Ensure efficient.

Table 2 shows 162 patients daily visits for dental treatment during morning hours while a total number

Table 2. The number of patients' daily visits in PLK UNAIR dental unit for the period of February 13-10 March 2017

\begin{tabular}{cc}
\hline Time & Total \\
\hline Morning & 162 \\
Afternoon & 197 \\
\hline Total & $\mathbf{3 5 9}$ \\
\hline
\end{tabular}

Source: Company Profile PLK UNAIR 2017 of 197 patients' daily visits for dental treatment during afternoon hours. The overall total number of patients' visits to Poly Dental Unit summed up to 359 during the period of 13 February 2017 to 10 March 2017. As a result of the high influx of patients' visits to PLK UNAIR, services provided by the dentist and the administrators, results show that there are friendly rates and the clinic caters the best service possible for the community. The current influx of patients will help the administrators to cater for the future influx. In other words, it can be used as a source of prediction for future expansion of the clinic in terms of personnel, infrastructural development and facilities. It will build the patients' confidence for subsequent visits. Hence the patients will be indirect marketers for the clinic. Duties, functions and job description of dentist in PLK UNAIR are illustrated in the table 3 (PLK, 2017).

Based on table 3, traces show duties, functions and job description of dentist in PLK UNAIR. Each dentist employed at PLK UNAIR is obligated to follow standard operational procedures within the institution and to perform a given task at the most appropriate time. All dentists are performing the same function and task on a daily basis. Dentists in PLK UNAIR understand the nature and causes of oral health Dentists in PLK UNAIR have the knowledge and techniques needed to diagnose and treat human injuries, diseases and deformities. They are oriented in their perspectives and perform administrative activities related to the medical service of Poly Dental. Being self-managed, self-developed and self-coached, will help the institution to make better decisions towards the quality services catered for the patients. Dentists are obligated to follow the regulations of PLK UNAIR and to ensure a satisfactory and timely same day treatment. Dentist provides dental education to patients regarding the best oral habits. Patients are treated in a friendly manner; this is one of the key roles of dentists to attract patients in order to boosts the clinics' standards. Dentists work closely with the dental nurse and administrators for effective communication in order to run the unit much more efficiently (PLK, 2017).

\section{Human Resources}

Human resource is the design of formal systems within an organization to ensure effective and efficient use of human talent to achieve organizational goals (Robert \& Jackson, 2010). Similarly, (Chartered Institute of Personnel and Development, 2005) argues that HR are expressed as designed, implementation and maintenance strategies to manage people for optimal business performance including development policies and processes to support the strategy. Human resource is a specialized business field that focuses on the recruitment and management of the people. It typically deals with the compensation, benefits, hiring, firing safety wellness, and training. Human Resources Management, in particular, can be defined as a system of activities and strategies that focus on successfully managing employees at all levels of an organization to achieve organizational goals (Bayrs \& Rue, 2004). Furthermore, he stressed that employees are the human resources of an organization and it is the utmost valuable asset. Furthermore, to be 
Table 3. Duties and Functions and Description of duties for Dentist in PLK UNAIR

\begin{tabular}{lll}
\hline \multicolumn{1}{c}{ Office } & \multicolumn{1}{c}{ Duties and Functions } & \multicolumn{1}{c}{ Job Description } \\
\hline Dentist PLK & 1. Conducting medical, dental and oral care. & 1. Dental examination and treatment. \\
UNAIR & 2. Perform Administrative activities related to & 2. Making of Dentures. \\
& the medical services of Poly Dental. & 3. Patient Referral. \\
& 3. Organize internal activities at PLK & 4. Reporting of dental medical services. \\
UA \& UNAIR. & 5. Follow internal training. \\
& 4. Self-development. & 6. Conducting oral health education. \\
& & 7. Obligated to follow and conduct the SOP within the Poly \\
& & Dental \\
\hline
\end{tabular}

Source: Company Profile PLK UNAIR 2015

successful, an organization must make employee productivity a major goal. Human resources in PLK UNAIR comprises of productive administration that works as a driver of the institution. Human resource performs its duties by conducting training to the overall administration within PLK UNAIR. Human resource is the backbone of PLK UNAIR. It is an important asset to the institution and therefore should be kept in the formation to achieve the goal of the institution.

Human resources professionals in PLK UNAIR are employed to help manage human capital within the institution. It is focused on managing the personnel in PLK UNAIR to increase its effectiveness. PLK UNAIR is managed by the human resource professionals by boosting the employees' productivity. The human resource is PLK UNAIR comply with staff turnover. Employee appraisals are being measured as to produce good results. PLK UNAIR consists of a small size which makes it easier for the human resources to conduct performance appraisal within the institution.

The HR planning reviews the institution's mission, objectives and strategies. Determines how many administrators are available currently and with what qualifications. Job vacancies for PLK UNAIR are advertised by the human resources department. They are the decision-makers and responsible for the number of potential candidates that will be hired. Its purpose is to improve the productive contribution of employees who are employed with PLK UNAIR. Employee satisfaction is identified in the formation of human resource that boosts employee satisfaction with the sense to support the institutions' goals. Employees in PLK UNAIR have a passion for working with patients as well as careful listening, speaking, and problem solving. HR provides a significant support and advice to line management and examine the various $\mathrm{HR}$ processes that are concerned with attracting, managing, motivating and developing employees for the benefit of the institution.

\section{CONCLUSION}

The flow of administrative service within the dental unit in PLK, the activities of employees has been directed toward achieving a goal. As for the development in PLK, it is designed to assist the institution whether it consists of the needed internal talent that will meet the future human resource candidates. HR works hard to facilitate the system within the institution for wide changes and for the better. Motivation set the performance standard for each employee. The organizational structure is identified. Broad vision statement such as: being the First Health Facilities owned in Indonesia. This is transformed into specific behaviors by assisting employees to figure out what work they can keep doing to make their vision real. Employees are engaged fully because they believe they are valued, recognized, sharing ideas, hard workers and relate better to patients.

PLK UNAIR on future career development has implemented an apprenticeship program to enhance the UNAIR graduates' soft and hard skills for on a real professional platform. It is a structured constructive program that offers students the ongoing training during the internship by preparing themselves for career endeavours. Data derived from the apprenticeship show various activities that were undertaken by the student during the duration of the apprenticeship. The patient flow in PLK UNAIR Dental Unit is identified and has resulted in a high influx of daily patient visits. The evidence shows the friendly rates of student patients receiving free services. PLK UNAIR at its best capacity has served the community for decades due to the affordable fees and flexible health programs. The company's Profile Book consists of information on services provided by PLK UNAIR and BPJS free for the public eye.

\section{REFERENCES}

Bayrs, L.L. \& Rue, W.L. 2004. Human Resource Management. 7th ed. Boston: McGraw-Hill, 2004.

Chartered Institute of Personnel and Development (Great Britain) (CIPD). 2005. Chartered Institute of Personnel Development (CIPD) Annual Survey Report, 2005: Training and Development. [Online] Available at: http:hdl.voced.edu.au/10707/8806.

Decenzo, D., \& Robbinsons, S.P. 2010. Human resource management $\left(10^{\text {th }}\right.$ ed.). Singapore: South-Western.

Devers, C.E. et al., 2009. Taking Stock of What We Know about Mergers and Acquisitions: A review and Research Agenda. Journal of Management, 35(3), pp. 469-502.

Douglas, C.H. \& Douglas, M.R. 2004. Patient-friendly Hospital Environments: Exploring the Patients' 
Perspective. An International Journal of Public Participation in Health Care and Health Policy, 1(7), pp. 61-73.

Hadipranata, A.F. 1996. MIKEO IS NOT MBO. Bulletin of Psychology, 4(1).

Mbalamula, Y.S., Suru, M.H. \& Seni, A.J. 2017. Utility of Henry Fayol's Fourteen Principles in the Administration Process of Secondary School in Tazmania. International Journal of Education and Research, V(6), pp. 103-116.

Ministry of Health Indonesia. 2014. Health Regulation No. 9, 2014. Jakarta.

Ministry of Health Indonesia. 2014. Regulations of Dental Health Services No. 1. Jakarta.

PLK. 2017. Company Profile. Surabaya: PLK UNAIR.

PLK UNAIR. 2017. Company Profile PLK UNAIR 2017. Surabaya: Universitas Airlangga.
PLK UNAIR. 2017. Job Description PLK UNAIR 2017. Surabaya: Universitas Airlangga.

PLK. 2017. Company Profile. Surabaya: PLK UNAIR.

Robert, M.L. \& Jackson, J.H. 2010. Human Resource Management. 13th ed. Omaha: Joseph Sabatino.

Stillman, R. 2008. Review Article: Dwight Waldo's the Administrative state: A Neglected American Administrative State Theory for Our Times. Public Health administration, 86(2), pp. 581-590.

Thompson, H.A.S.a.V.A. 1991. The Reissue of Simon, Smithburg, and Thompson's "Public Administration". Journal of Public Administration Research and Theory: J-PART, 1(1), pp. 75-88 (14 pages). 